\title{
REVIEW
}

\section{Off-pump coronary artery bypass graft surgery: the incidence of postoperative atrial fibrillation}

\section{R A Archbold, N P Curzen}

Atrial fibrillation (AF) occurs in one quarter to one third of patients after coronary artery bypass graft surgery ( $C A B G$ ). Conventional CABG uses cardiopulmonary bypass, a process that is itself associated with a systemic vascular inflammatory response that contributes to postoperative morbidity. The avoidance of cardiopulmonary bypass is associated with a significant reduction in the inflammatory response and in the release of markers of myocardial necrosis when compared with conventional CABG. There is speculation that off-pump CABG may reduce the incidence of postoperative AF through reduced trauma, ischaemia, and inflammation. Current data, however, do not emphatically answer the question of whether the incidence of post-CABG AF is reduced by off-pump surgery. The evidence from both observational and randomised studies is conflicting and many studies have weaknesses in design, conduct, or interpretation. It remains an attractive hypothesis that postoperative $A F$ is reduced by off-pump CABG but more robust data are required.

See end of article for authors' affiliations

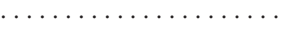

Correspondence to: Dr R A Archbold, Department of Cardiology, St Bartholomew's Hospital, Dominion House, 60 Bartholomew Close, West Smithfield, London ECIA 7BE, UK ; Andrew.Archbold@ bartsandthelondon.nhs.uk
A proximately 27000 people in the UK and 500000 people in the USA undergo coronary artery bypass graft surgery (CABG) annually, 25-30\% of whom develop atrial fibrillation (AF) postoperatively. AF is associated with increased morbidity and expenditure, and prolonged hospital stay after CABG. ${ }^{1}$ Advances in surgical techniques have not been accompanied by a decrease in the incidence of post-CABG AF. However, the use of "off-pump" CABG may provide a novel solution to this problem. This review analyses the current evidence regarding the incidence of AF after off-pump CABG.

\section{PATHOGENESIS OF POST-CABG AF: A ROLE FOR THE "POST-PUMP SYNDROME"?}

The pathogenesis of post-CABG AF is incompletely understood. Evidence suggests that the patients at greatest risk of developing the arrhythmia have an identifiable electrophysiological substrate. ${ }^{2}$ The nature of this substrate may be slow atrial conduction or dispersion of atrial refractoriness. ${ }^{3}$ A number of perioperative factors, such as inadequate myocardial protection, electrolyte imbalance, $\beta$ blocker withdrawal, change in autonomic tone, or the response to cardiopulmonary bypass $(\mathrm{CPB})$, may precipitate $\mathrm{AF}$ in these patients.

Conventional CABG employs CPB during the period of cardiac arrest. This provides for extracorporeal oxygenation of blood before returning it to the systemic circulation, thus ensuring adequate delivery to the vital organs. CPB is itself associated with a systemic inflammatory response syndrome that contributes to postoperative morbidity. ${ }^{4}$ Post-pump syndrome is characterised by leucocytosis, increased capillary permeability, accumulation of interstitial fluid, and organ dysfunction. It is thought to be triggered by surgical trauma, lung reperfusion, and contact of blood with the "foreign" extracorporeal bypass circuit.

Currently only circumstantial evidence suggests a causal relation between CPB and postoperative $\mathrm{AF}$, a minority of investigators having reported an association between bypass time and post-CABG AF. ${ }^{5}$ Nevertheless, it remains an attractive hypothesis that the avoidance of $\mathrm{CPB}$ will reduce the incidence of post-CABG AF.

\section{DOES OFF-PUMP CABG REDUCE THE INCIDENCE OF POST-CABG AF? THE TRIAL EVIDENCE}

There is considerable interest in beating heart surgery without $\mathrm{CPB}$ and minimally invasive direct coronary artery bypass (MIDCAB), both of which may reduce postoperative morbidity. Offpump CABG is associated with a significant reduction in the inflammatory response ${ }^{6}$ and in the release of markers of myocardial necrosis ${ }^{7}$ compared with conventional CABG. Furthermore, there are now data assessing the incidence of AF in patients revascularised by these techniques (tables 1 and 2). ${ }^{8-52}$

In two series, post-CABG AF occurred in 18 $(5.9 \%)$ of 306 patients who underwent left internal mammary artery grafting to the left anterior descending artery by MIDCAB ${ }^{23}$ and was recorded in only $34(1.7 \%)$ of 2052 patients who had off-pump CABG by median sternotomy. ${ }^{25}$ In a study of patients who underwent CABG by MID$\mathrm{CAB} \quad(\mathrm{n}=93)$ or conventional operation $(\mathrm{n}=74)$, AF was less frequent $(7 \% \vee 31 \%$, respectively; $\mathrm{p}<0.05$ ) in the group without CPB. ${ }^{10} \mathrm{By}$ contrast, different series have reported rates of $\mathrm{AF}$

Abbreviations: $A F$, atrial fibrillation; $C A B G$, coronary artery bypass graft surgery; $\mathrm{CPB}$, cardiopulmonary bypass; MIDCAB, minimally invasive direct coronary artery bypass 
Table 1 Incidence of AF after conventional and minimally invasive direct CABG

\begin{tabular}{|c|c|c|c|}
\hline \multirow[b]{2}{*}{ Study, year (reference) } & \multicolumn{2}{|c|}{ Incidence of postoperative AF } & \multirow[b]{2}{*}{$\mathrm{p}$ Value } \\
\hline & CPB & Non-CPB & \\
\hline Allen 1997* (8) & $7 / 12$ (58\%) & $0 / 23(0 \%)$ & 0.0001 \\
\hline Collard 1997 (9) & NA & $1 / 10(10 \%)$ & NA \\
\hline Allen $1998(10)$ & $23 / 74(31 \%)$ & $6 / 93(7 \%)$ & $<0.05$ \\
\hline Calafiore 1998 (11) & NA & $35 / 434(8 \%)$ & NA \\
\hline Jansen 1998 (12) & NA & $5 / 54(9.3 \%)$ & NA \\
\hline Tamis 1998 (13) & $11 / 33(33 \%)$ & $11 / 42(26 \%)$ & NS \\
\hline Arom 1999 (14) & $39 / 243(16 \%)$ & $8 / 44(18 \%)$ & NA \\
\hline Cohn 1999 (15) & $11 / 55(20 \%)$ & $13 / 55(24 \%)$ & 0.6 \\
\hline Abreu 1999 (16) & $192 / 747(26 \%)$ & $4 / 34(12 \%)$ & 0.06 \\
\hline Turner Jr 1999 (17) & NA & $5 / 100(5 \%)$ & NA \\
\hline Siebert 2000 (18) & $7 / 39(18 \%)$ & $6 / 24(25 \%)$ & NS \\
\hline Stamou 2000 (19) & NA & $40 / 292(14 \%)$ & NA \\
\hline Koutlas $2000 \dagger(20)$ & $57 / 220(26 \%)$ & $14 / 53(26 \%) \ddagger$ & NS \\
\hline d'Amato 2000 (21) & $14 / 42(28 \%)$ & $4 / 96(4 \%)$ & 0.003 \\
\hline Tamis-Holland 2000 (22) & $42 / 108(39 \%)$ & $23 / 101$ (23\%) & 0.02 \\
\hline Cremer $2000(23)$ & NA & $18 / 306(5.9 \%)$ & NA \\
\hline Hravnak 2001 (24) & $238 / 720(33.1 \%)$ & $22 / 94(23.4 \%)$ & 0.059 \\
\hline
\end{tabular}

of up to $37 \%$ despite no $\mathrm{CPB},{ }^{26}$ while other observational studies have shown no difference in AF incidence post-CABG with and without CPB. ${ }^{16} 20$

Theoretically, any reduction in AF incidence after off-pump CABG may be attributed to the less invasive nature of MIDCAB procedures than of median sternotomy rather than to the absence of CPB. In 969 patients who underwent CABG without $\mathrm{CPB}$, for example, MIDCAB was associated with a lower incidence of $\mathrm{AF}$ ( $14 \% \vee 25 \%$; odds ratio $0.4,95 \%$ confidence interval 0.3 to $0.7 ; \mathrm{p}<0.001$ ) than a median sternotomy approach. ${ }^{19}$ Specific information about the impact of $\mathrm{CPB}$ on postoperative AF therefore comes from studies

\begin{tabular}{|c|c|c|c|}
\hline \multirow[b]{2}{*}{ Study, year (reference) } & \multicolumn{2}{|c|}{ Incidence of postoperative AF } & \multirow[b]{2}{*}{$\mathrm{p}$ Value } \\
\hline & CPB & Non-CPB & \\
\hline Collard 1997 (9) & NA & $22 / 66(33 \%)$ & NA \\
\hline Jansen 1998 (12) & NA & $7 / 46(15.2 \%)$ & NA \\
\hline Tasdemir 1998 (25) & NA & $34 / 2052(1.7 \%)$ & NA \\
\hline Saatvedt 1999 (26) & $248 / 685(36 \%)$ & $7 / 19(37 \%)$ & NS \\
\hline Spooner 1999 (27) & NA & $44 / 331(13.3 \%)^{*}$ & NA \\
\hline Boyd $1999(28)$ & $17 / 60(28.3 \%)$ & $3 / 30(10 \%) \dagger$ & $<0.05$ \\
\hline Ardehali 1999 (29) & NA & $5 / 26(19 \%)$ & NA \\
\hline Arom $1999(14)$ & $39 / 243(16 \%)$ & $8 / 62(13 \%)$ & NS \\
\hline Cartier $2000(30)$ & $580 / 1870(31 \%)$ & $90 / 300(30 \%)$ & 0.8 \\
\hline Siebert 2000 (18) & $7 / 39(18 \%)$ & $7 / 24(29 \%)$ & NS \\
\hline Stamou 2000 (19) & NA & $166 / 677(25 \%)$ & NA \\
\hline Stamou $2000^{* * *}(31)$ & $12 / 41(29 \%)$ & $13 / 91(14 \%) \ddagger$ & 0.04 \\
\hline Ascione 2000 (32) & $39 / 100(39 \%)$ & $8 / 100(8 \%)$ & 0.001 \\
\hline Arom 2000 (33) & $721 / 3171$ (23\%) & $50 / 350(14 \%)$ & $<0.001$ \\
\hline Kshettry 2000 (34) & $131 / 609(21.5 \%)$ & $24 / 135$ (17.8\%) & NS \\
\hline Hart $2000(35)$ & NA & $236 / 1582(14.9 \%) \S$ & NA \\
\hline Arom $20009(36)$ & $31 / 132(23 \%)$ & $6 / 45(13.3 \%)$ & 0.154 \\
\hline Hernandez 2000 (37) & $102 / 445(22.9 \%)$ & $63 / 332(19.0 \%)$ & NS \\
\hline Omeroglu 2000 (38) & NA & $5 / 70(7.1 \%)$ & NA \\
\hline Bedi 2000 (39) & NA & $1 / 100(1 \%)$ & NA \\
\hline Kilger 2001 (40) & $9 / 53(17 \%)$ & $2 / 50(4 \%)$ & $<0.05$ \\
\hline Czerny 2001 (41) & $7 / 40(17.5 \%)$ & $5 / 40(12.5 \%)$ & NS \\
\hline Bull 2001 (42) & $7 / 40(18 \%)$ & $7 / 40(18 \%)$ & NS \\
\hline Yeatman 2001 * * (43) & $38 / 312(12.2 \%)$ & $9 / 75(12 \%)$ & 0.95 \\
\hline Bowles 2001 (44) & $24 / 70(34 \%)$ & $22 / 67(33 \%)$ & NS \\
\hline Calafiore 2001 (45) & $111 / 924(12 \%)$ & $110 / 919(12 \%)$ & NS \\
\hline Siebert 2001 (46) & $64 / 650(9.8 \%)$ & $12 / 118(10.2 \%)$ & $0.9+\dagger$ \\
\hline Arom $2001 \ddagger \ddagger(47)$ & NA & $56 / 342(16.4 \%)$ & NA \\
\hline Puskas 2001 (48) & $158 / 1000$ (15.8\%) & $25 / 200(12.5 \%)$ & 0.28 \\
\hline Demers $2001 \S \S(49)$ & $268 / 497(54 \%)$ & $41 / 98(42 \%)$ & 0.05 \\
\hline Lund 2001 (50) & $109 / 368(29.6 \%)$ & $37 / 165(22.4 \%)$ & NS \\
\hline Van Dijk 2001 (51) & $29 / 139(21 \%)$ & $28 / 142(20 \%)$ & 0.79 \\
\hline Al-Ruzzeh 2001 ฯा (52) & $35 / 84(41 \%)$ & $16 / 56(29 \%)$ & 0.15 \\
\hline
\end{tabular}

*Mixed approaches; $\uparrow>70$ years old and $93 \%$ by median sternotomy; $\ddagger 56 \%$ by median sternotomy; $\S 83 \%$ by median sternotomy; Iejection fraction $\leqslant 30 \%$; * left main stenosis $\geqslant 50 \%$; ††AF incidence on intensive care unit (mean two days); $\ddagger$ fejection fraction $>30 \% ; \S \S \geqslant 70$ years; $\mathbb{\|} \geqslant 75$ years; ${ }^{*} * *$ single vessel repeat coronary artery bypass graft surgery. 
comparing patients undergoing median sternotomy with and without CPB. Thus, AF occurred in $23 \%$ of 3171 patients who underwent conventional CABG compared with $14 \%$ of 350 off-pump operations performed through sternotomy $(\mathrm{p}<0.001) .{ }^{33}$ Objective comparison is, however, difficult since the off-pump patients received fewer grafts, had shorter surgery, and were ventilated for a shorter period. Furthermore, in other studies, the incidence of AF was not significantly different in groups undergoing CABG by median sternotomy with and without CPB. ${ }^{26} 48$

The importance of considering differences in clinical characteristics is illustrated by a recent study in which the incidence of post-CABG AF was significantly lower $(23 \% v$ $39 \% ; p=0.02$ ) among 101 MIDCAB patients than in 108 on-pump patients. ${ }^{22}$ The MIDCAB patients were younger, had a lower frequency of previous cardiac surgery, had less extensive coronary disease, received fewer grafts, and had a shorter postoperative hospital stay. After adjustment for these differences, surgical method was no longer a significant predictor of AF.

To elucidate the role of $\mathrm{CPB}$ properly in post-CABG AF, randomised data are required. In one study, 200 low risk patients were randomly assigned to off-pump or conventional CABG. ${ }^{32}$ Sustained AF (> 10 minutes) was significantly less common $(8 \% \vee 39 \% ; p=0.001)$ in the off-pump group. Indeed CPB was the only independent predictor of postoperative AF. These data, however, contrast with those from a more recent trial in which 281 patients undergoing first, elective, isolated CABG were randomly assigned to on- or off-pump surgery. ${ }^{51}$ All patients received sotalol prophylaxis. Off-pump CABG resulted in reduced creatine kinase MB fraction release, reduced use of blood products, and a shorter hospital stay compared with on-pump surgery, but nevertheless the incidence of $\mathrm{AF}$ $(20 \% \vee 21 \%$, respectively; $\mathrm{p}=0.79)$ was similar.

\section{DISCUSSION}

Post-CABG AF continues to affect morbidity, hospital stay, and financial resources. There is speculation that off-pump CABG may reduce the incidence of $\mathrm{AF}$, but current data do not answer this hypothesis. The evidence is conflicting. Interpretation of studies is confounded by patient selection, inappropriate control groups, and poorly defined arrhythmia monitoring.

Alternative strategies for reducing both the inflammatory response to $\mathrm{CPB}$ and the incidence of post-CABG AF exist. $\beta$ Blockers are generally accepted to prevent $\mathrm{AF}^{53}$ Some studies have reported a reduction in the serum concentration of inflammatory markers after $\mathrm{CPB}$ using heparin coated extracorporeal circuits, or by high dose aprotinin or prednisolone. ${ }^{54}$ Whether these findings translate into clinical benefit, specifically a decrease in the incidence of post-CABG $\mathrm{AF}$, remains uncertain.

\section{Conclusion}

Off-pump techniques offer several potential advantages over conventional CABG (shorter operation times, more rapid recovery times, reduced neurocognitive impairment, reduced need for blood products). It is uncertain whether a reduction in the incidence of postoperative AF can be added to this list. More robust data are required.

\section{Authors' affiliations}

R A Archbold, Department of Cardiology, St Bartholomew's Hospital, London, UK

N P Curzen, Manchester Heart Centre, Manchester Royal Infirmary, Manchester, UK

\section{REFERENCES}

1 Archbold RA, Curzen N. Atrial fibrillation after coronary artery bypass graft surgery: more than an irritation! Clin Intensive Care 1999;10:109-16.
2 Zaman AG, Archbold RA, Helft G, et al. Atrial fibrillation after coronary artery bypass surgery: a model for pre-operative risk stratification. Circulation 2000;101:1403-8.

3 Cox JL, Schuessler RB, Boineau JP. The surgical treatment of atrial fibrillation I: summary of the current concepts of the mechanisms of atrial flutter and fibrillation. J Thorac Cardiovasc Surg 1991;101:402-5.

4 Butler J, Rocker GM, Westaby S. Inflammatory response to cardiopulmonary bypass. Ann Thorac Surg 1993;55:552-9.

5 Roffman JA, Fieldman A. Digoxin and propranolol in the prophylaxis of supraventricular tachydysrhythmias after coronary artery bypass surgery. Ann Thorac Surg 1981;31:496-501.

6 Gu YJ, Mariana MA, van Oeveren W, et al. Reduction of the inflammatory response in patients undergoing minimally invasive coronary artery bypass grafting. Ann Thorac Surg 1998;65:420-4.

7 Kilger E, Pichler B, Weis F, et al. Markers of myocardial ischaemia after minimally invasive and conventional coronary operation. Ann Thorac Surg 2000:70:2023-8.

8 Allen KB, Matheny RG, Robison RJ, et al. Minimally invasive versus conventional reoperative coronary artery bypass. Ann Thorac Surg 1997;64:616-22

9 Collard E, Ducart A, Buche $M$, et al. Postoperative morbidity after coronary artery bypass graft surgery without cardiopulmonary bypass [abstract]. Br J Anaesth 1997;78(suppl 2):43.

10 Allen KB, Matheny RG, Heimansohn DA, et al. Minimally invasive direct coronary artery bypass grafting versus single vessel conventional coronary artery bypass [abstract]. J Am Coll Cardiol 1998;31/suppl A):70A.

11 Calafiore AM, Di Giammarco G, Teodori G, et al. Midterm results after minimally invasive coronary surgery (LAST operation). J Thorac Cardiovasc Surg 1998;115:763-71.

12 Jansen EWL, Borst C, Lahpor JR, et al. Coronary artery bypass grafting without cardiopulmonary bypass using the octopus method: results in the first one hundred patients. J Thorac Cardiovasc Surg 1998;1 16:60-7.

13 Tamis JE, Vloka ME, Malhotra S, et al. Atrial fibrillation is common after minimally invasive direct coronary artery bypass graft surgery [abstract]. J Am Coll Cardiol 1998;31(suppl A): 118 A.

14 Arom KV, Emery RW, Flavin TF, et al. Cost-effectiveness of minimally invasive coronary artery bypass surgery. Ann Thorac Surg 1999:68:1562-6.

15 Cohn WE, Sirois CA, Johnson RG. Atrial fibrillation after minimally invasive coronary artery bypass grafting: a retrospective, matched study. J Thorac Cardiovasc Surg 1999;117:298-301.

16 Abreu JE, Reilly J, Salzano RP, et al. Comparison of frequencies of atrial fibrillation after coronary artery bypass grafting with and without the use of cardiopulmonary bypass. Am J Cardiol 1999;83:775-6.

17 Turner WF Jr. "Off-pump" coronary artery bypass grafting: the first one hundred cases of the Rose City experience. Ann Thorac Surg 1999;68: 1482-5.

18 Siebert J, Rogowski J, Jagielak D, et al. Atrial fibrillation after coronary artery bypass grafting without cardiopulmonary bypass. Eur J Cardiothorac Surg 2000;17:520-3

19 Stamou SC, Dangas G, Hill PC, et al. Atrial fibrillation after beating heart surgery. Am J Cardiol 2000;86:64-7.

20 Koutlas TC, Elbeery JR, Williams JM, et al. Myocardial revascularization in the elderly using beating heart coronary artery bypass surgery. Ann Thorac Surg 2000;69: 1042-7.

21 d'Amato TA, Savage EB, Wiechmann RJ, et al. Reduced incidence of atrial fibrillation with minimally invasive direct coronary artery bypass. Ann Thorac Surg 2000;70:2013-6.

22 Tamis-Holland JE, Homel P, Durani $M$, et al. Atrial fibrillation after minimally invasive direct coronary artery bypass surgery. J Am Coll Cardiol 2000;36: 1884-8.

23 Cremer JT, Wittwer T, Böning A, et al. Minimally invasive coronary artery revascularization on the beating heart. Ann Thorac Surg 2000;69:1787-91.

24 Hravnak M, Hoffman LA, Saul MI, et al. Atrial fibrillation: prevalence after minimally invasive direct and standard coronary artery bypass. Ann Thorac Surg 2001;71:1491-5

25 Tasdemir O, Vural KM, Karagoz $\mathrm{H}$, et al. Coronary artery bypass grafting on the beating heart without the use of extracorporeal circulation: review of 2052 cases. J Thorac Cardiovasc Surg 1998; 116:68-73.

26 Saatvedt K, Fiane AE, Sellevold O, et al. Is atrial fibrillation caused by extracorporeal circulation? Ann Thorac Surg 1999;68:931-3.

27 Spooner TH, Hart JC, Pym J. A two-year, three institution experience with the Medtronic Octopus: systematic off-pump surgery. Ann Thorac Surg 1999;68:1478-81

28 Boyd WD, Desai ND, Del Rizzo DF, et al. Off-pump surgery decreases postoperative complications and resource utilization in the elderly. Ann Thorac Surg 1999;68:1490-3.

29 Ardehali A, Kessler D, Faroushani F, et al. Multivessel coronary artery bypass without cardiopulmonary bypass. Am Heart J 1999;138:983-6.

30 Cartier R, Brann S, Dagenais F, et al. Systematic off-pump coronary atery revascularization in multivessel disease: experience of three hundred cases. J Thorac Cardiovasc Surg 2000;119:221-9.

31 Stamou SC, Pfister AJ, Dangas G, et al. Beating heart versus conventional single-vessel reoperative coronary artery bypass. Ann Thorac Surg 2000;69:1383-7

32 Ascione $\mathbf{R}$, Caputo $M$, Calori $G$, et al. Predictors of atrial fibrillation after conventional and beating heart coronary surgery: a prospective, randomized study. Circulation 2000;102:1530-5.

33 Arom KV, Flavin TF, Emery RW, et al. Safety and efficacy of off-pump coronary artery bypass grafting. Ann Thorac Surg 2000;69:704-10. 
34 Kshettry VR, Flavin TF, Emery RW, et al. Does multivessel, off-pump coronary artery bypass reduce postoperative morbidity? Ann Thorac Surg 2000;69: 1725-31

35 Hart JC, Spooner TH, Pym J, et al. A review of 1,582 consecutive octopus off-pump coronary bypass patients. Ann Thorac Surg 2000;70:1017-20

36 Arom KV, Flavin TF, Emery RW, et al. Is low ejection fraction safe for off-pump coronary bypass operation? Ann Thorac Surg 2000;70: 1021-5

37 Hernandez F, Clough RA, Klemperer JD, et al. Off-pump coronary artery bypass grafting: initial experience at one community hospital. Ann Thorac Surg 2000;70: 1070-2.

38 Omeroglu SN, Kurali K, Güler M, et al. Midterm angiographic assessment of coronary atery bypass grafting without cardiopulmonary bypass. Ann Thorac Surg 2000;70:844-50.

39 Bedi HS, Suri A, Kalkat MS, et al. Global myocardial revascularization without cardiopulmonary bypass using innovative techniques for myocardial stabilization and perfusion. Ann Thorac Surg 2000;69:156-64

40 Kilger E, Weis FC, Goetz AE, et al. Intensive care after minimally invasive and conventional coronary surgery: a prospective comparison. Intensive Care Med 2001;27:534-9

41 Czerny M, Baumer H, Kilo J, et al. Complete revascularization in coronary artery bypass grafting with and without cardiopulmonary bypass. Ann Thorac Surg 2001;71:165-9.

42 Bull DA, Neumayer LA, Stringham JC, et al. Coronary artery bypass grafting with cardiopulmonary bypass versus off-pump cardiopulmonary bypass grafting: does eliminating the pump reduce morbidity and cost? Ann Thorac Surg 2001:71:170-5.

43 Yeatman $M$, Caputo $M$, Ascione R, et al. Off-pump coronary artery bypass surgery for critical left main stem disease: safety, efficacy and outcome. Eur J Cardiothorac Surg 2001;19:239-44

44 Bowles BJ, Lee JD, Dang CR, et al. Coronary artery bypass performed without the use of cardiopulmonary bypass is associated with reduced cerebral microemboli and improved clinical results. Chest $2001 ; 119: 25-30$

45 Calafiore AM, Di Mauro M, Contini M, et al. Myocardial revascularization with and without cardiopulmonary bypass in multivessel disease: impact of the strategy on early outcome. Ann Thorac Surg $2001 ; 72: 456-63$.

46 Siebert J, Anisimowicz L, Lango R, et al. Atrial fibrillation after coronary artery bypass grafting: does the type of procedure influence the early postoperative incidence? Eur J Cardiothorac Surg 2001; 19:455-9.

47 Arom KV, Emery RW, Flavin TF, et al. OPCAB surgery: a critical review of two different categories of pre-operative ejection fraction. Eur $J$ Cardiothorac Surg 2001;20:533-7

48 Puskas JD, Thourani VH, Marshall J, et al. Clinical outcomes, angiographic patency, and resource utilization in 200 consecutive off-pump coronary bypass patients. Ann Thorac Surg 2001;71:1477-84.

49 Demers P, Cartier R. Multivessel off-pump coronary artery bypass surgery in the elderly. Eur J Cardiothorac Surg 2001;20:908-12.

50 Lund $\mathrm{O}$, Christensen J, Holme $\mathrm{S}$, et al. On-pump versus off-pump coronary artery bypass: independent risk factors and off-pump graft patency. Eur J Cardiothorac Surg 2001;20:901-7.

51 van Dijk D, Nierich AP, Jansen EWL, et al for the Octopus Study Group. Early outcome after off-pump versus on-pump coronary bypass surgery. Results from a randomized study. Circulation 2001;104:1761-6.

52 Al-Ruzzeh S, George S, Yacoub M, et al. The clinical outcome of off-pump coronary artery bypass surgery in the elderly patients. Eur $\mathrm{J}$ Cardiothorac Surg 2001;20:1 152-6.

53 Crystal E, Connolly SJ, Sleik K, et al. Interventions on prevention of postoperative atrial fibrillation in patients undergoing heart surgery: a meta-analysis. Circulation 2002;106:75-80

54 Harig F, Feyer R, Mahmoud FO, et al. Reducing the post-pump syndrome by using heparin-coated circuits, steroids, or aprotinin. Thorac Cardiovasc Surg 1999;47:111-8.

\section{IMAGES IN CARDIOLOGY}

\section{Life threatening total occlusion of the left coronary artery after acetylcholine infusion}

A 44 year old woman was referred to the hospital with anginal complaints and ST segment changes during exercise. A coronary angiogram was performed, but no stenoses were found. As her complaints persisted the question arose as to whether this could be caused by coronary spasm. Therefore it was decided to perform an acetylcholine provocation test. Acetylcholine was infused into the left main artery at a rate of $0.22 \mu \mathrm{g} / \mathrm{min}$. After two minutes, the patient experienced severe anginal pain and the ECG showed ST segment elevations. Another angiogram was taken and revealed

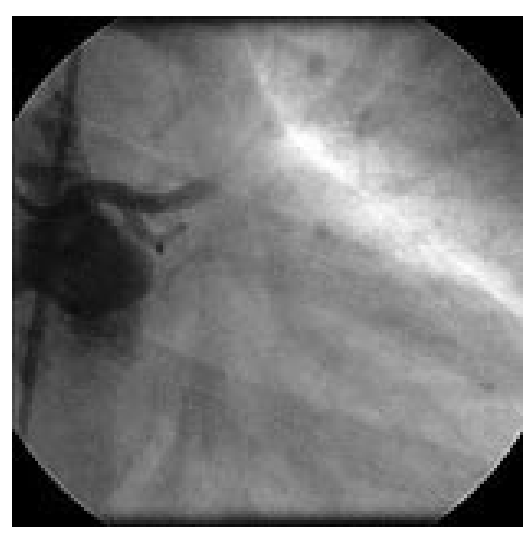

severe coronary spasm of both the left anterior descending (LAD) and the circumflex (CX) coronary arteries (below left). A bolus of glyceryl trinitrate was given intracoronary to achieve vasodilation. This action was repeated, but with no satisfactory result. Subsequently, an intracoronary bolus of atropine $(500 \mu \mathrm{g})$ was given as a last resort to terminate the spasm. After one dose of atropine the CX was open again, whereas the distal LAD remained closed (below centre). A second bolus was needed to normalise the angiogram (below right) as well as the ECG. Although a slight increase in troponin was found after the procedure,

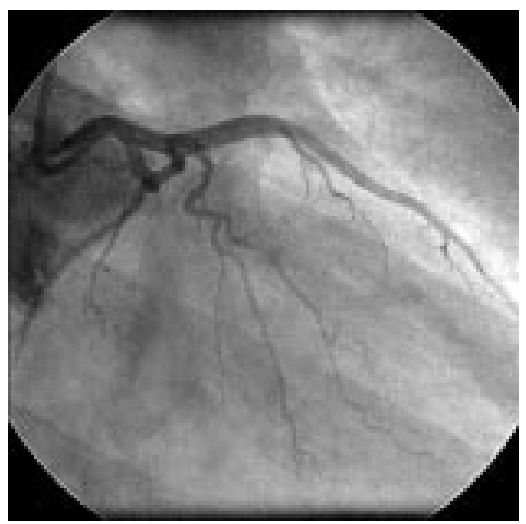

no major complications occurred and the patient was discharged from hospital two days later.

This case shows that life threatening coronary spasms can occur during acetylcholine infusion in patients with "normal" coronary arteries. More important, glyceryl trinitrate is not always capable of reversing the evoked coronary spasm. Intracoronary atropine infusion may establish a satisfying vasodilating effect in these cases.

J S Wijpkema

G A J Jessurun R A Tio r.a.tio@thorax.azg.nl

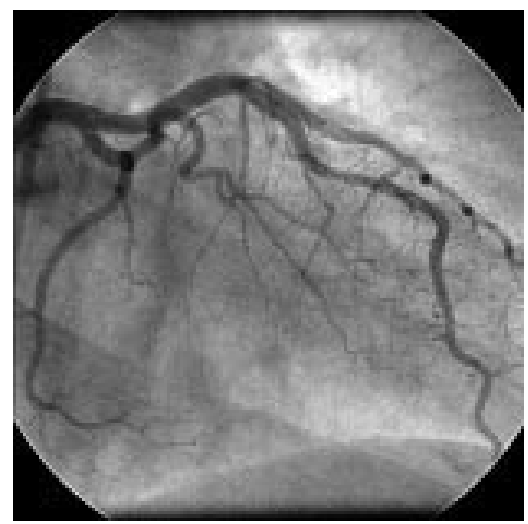

